\title{
PENDAMPINGAN PEMBUATAN KONTEN MEDIA BERBASIS SEO TERKAIT INFORMASI LINGKUNGAN DI KAMPUNG IKLIM PURWOKELING SEMARANG
}

\author{
Heni Indrayani ${ }^{1}$, Mukaromah ${ }^{2}$, Swita Amallia Hapsari ${ }^{3}$ \\ ${ }^{1,2,3}$ Program Studi Ilmu Komunikasi, Universitas Dian Nuswantoro \\ E-mail: ${ }^{1}$ heni.indrayani@dsn.dinus.ac.id, ${ }^{2}$ mukaromah@dsn.dinus.ac.id, \\ ${ }^{3}$ swita.amallia.hapsari@dsn.dinus.ac.id
}

\begin{abstract}
Abstrak
Kepedulian lingkungan menjadi nilai yang digerakkan di wilayah RW X Program Kampung Iklim Bhakti Persada Indah Semarang. Di wilayah ini pernah terjadi terjadi kebakaran lereng sisi utara RT 05 dan RT 09 pada tahun 2008 dan 2015 sehingga warga aktif melakukan beragam program lingkungan yang dikemas dalam Program Iklim Purwoyoso Kepedulian Lingkungan. Kepedulian lingkungan inilah yang menjadi konten publikasi agar dapat dicontoh wilayah lainnya. Namun, publikasi kegiatan hingga Maret 2020 masih berfokus pada publikasi media cetak saja sehingga jangkauannya kurang luas. Sedangkan publikasi secara online masih belum optimal dilakukan. Oleh karena itu, diperlukan pelatihan pemanfaatan SEO sebagai komunikasi online Program Kampung Iklim Bhakti Persada Indah Semarang. Hasil dari pengabdian masyarakat adalah penulisan release untuk berita online yang berdasarkan cara mengoptimalkan kata kunci di mesin pencari. SEO memungkinkan konten lingkungan dari Proklim Purwokeling sebagai publikasi online muncul di daftar hasil teratas mesin pencari. Pelatihan untuk memanfaatkan SEO sebagai komunikasi online Program Kampung Iklim Purwokeling Bhakti Persada Indah Semarang dengan membuat konten yang menarik dan tepat bisa semakin menarik masyarakat untuk lebih peduli dengan lingkungan dan menginspirasi melakukan hal yang sama demi keberlanjutan ekosistem
\end{abstract}

Kata kunci: Pelatihan penulisan online, Program Kampung Iklim, Proklim Purwokeling BPI, Search Engine Optimization (SEO)

\begin{abstract}
Environmental concern is a value that is driven in the area of $R W X$ Program Kampung Iklim Bhakti Persada Indah Semarang. In this area, there was a fire on the north slope of RT 05 and RT 09 in 2008 and 2015 so that residents actively carried out various environmental programs that were packaged in the Purwoyoso Environmental Care Program. This environmental concern is the content of the publication so that it can be emulated in other regions. However, the publication of activities until March 2020 still focuses on print media publications only so that their reach is not broad. Meanwhile, online publication is still not optimal. Therefore, training on the use of SEO as an online communication is required for the Program Kampung Iklim Bhakti Persada Indah Semarang. The result of this community service is writing releases for online news based on how to optimize keywords in search engines. SEO allows environmental content from Proklim Purwokeling as online publications to appear in the search engine top result lists. Training to use SEO as online communication Program Kampung Iklim Bhakti Persada Indah Semarang by creating interesting and appropriate content can increasingly attract people to care more about the environment and inspire to do the same for the sustainability of the ecosystem
\end{abstract}

Keywords: Online writing training, Program Kampung Iklim, Proklim Purwokeling BPI, Search Engine Optimization (SEO) 


\section{PENDAHULUAN}

Global warming menjadi isu utama dunia terkait perubahan iklim. Ada banyak hambatan dan tantangan yang terkait dengan komunikasi perubahan iklim yang berfokus pada mempromosikan tindakan berbasis masyarakat untuk masa depan yang berkelanjutan. Yang menarik adalah tantangan untuk menanamkan perspektif masyarakat dalam proses komunikasi solusi perubahan iklim. Lingkungan di pinggiran kota kini terus menjadi perhatian karena banyaknya polutan yang mencemari udara. Permasalahan lingkungan pun sudah semakin kompleks, tidak hanya masalah polusi udara tetapi juga berbagai krisis lingkungan yang lain seperti masalah ketersediaan air bersih, pengelolaan sampah, hingga sanitasi lingkungan [1]. Untuk mengatasinya maka perlu dicari solusi yang bisa membutuhkan seluruh elemen dari masyarakat untuk bergerak bersama. Masalah lingkungan ini dapat diatasi dengan mengelola lingkungan agar lebih hijau dengan penanaman atau bahkan masyarakat terlibat langsung untuk dapat mengurangi limbah dengan memanfaatkan menjadi barang yang bernilai.

Kota Semarang sebagai kota pesisir pulau Jawa bagian Utara juga menjadi salah satu wilayah yang rentan terhadap perubahan iklim. Kota Semarang terkenal dengan daerah bersuhu panas dibanding daerah lainnya di Jawa, karena lokasinya yang terdapat laut dan perbukitan. Permasalahan iklim seperti kekeringan, penuruan tanah, banjir, longsor menjadi persoalan akibat ketidakpedulian lingkungan oleh masyarakat. Salah satu solusinya adalah mengembangkan program kampung iklim.

Berdasarkan Peraturan Menteri LHK Nomor P.84 tahun 2016 tentang Program Kampung Iklim dan Perdirjen PPI Nomor: P.1 tahun 2017 tentang Pedoman Pelaksanaan Program Kampung Iklim, di Jawa Tengah memiliki 133 kampung iklim [2]. Salah satunya adalah Program Kampung Iklim Purwokeling Bhakti Persada Indah (BPI) RW X Kelurahan Purwoyoso Kecamatan Ngaliyan Kota Semarang. RW X di Kelurahan Purwoyoso berbatasan langsung dengan Kawasan Industri Candi, yang notabene adalah kawasan industri terbesar di Kota Semarang. Dengan luas wilayah 14,50 hektar dan terdiri dari 9 RT, program kampung iklim Purwokeling BPI sudah aktif sejak tahun 2009 dan SK resmi sebagai Proklim pada 2015.

Pada tahun 2008 dan 2015 pernah terjadi kebakaran lereng sisi utara RT 05 dan RT 09 sehingga warga aktif berupaya untuk lebih peduli lingkungan. Di RW X, warga berpartisipasi aktif dalam menghijaukan lingkungan dengan program kampung iklim antara lain (1) Adaptasi, yang meliputi: Pengendalian kekeringan, banjir, dan longsor yang meliputi Komposting, Pertanian, Lubang Sumur Resapain Air Hujan, Penadah Air Hujan, Lubang Biopori, pembuatan taman toga, ruang taman pkk, terbuka hijau, penanaman pohon pada lereng tebing. Peningkatan ketahanan pangan yang meliputi memanfaatkan lahan pekarangan untuk bertanam singkong, terong, dan lainnya, Pengendalian penyakit terkait iklim yang meliputi kegiatan menguras, menutup, mengubur, memeriksa jentik nyamuk, dan Penanganan atau antisipasi kenaikan muka laut, rob, intrusi air laut, abrasi, ablasi atau erosi akibat angin, gelombang tinggi. (2) Mitigasi, yang meliputi: pengelolaan sampah, limbah padat dan cair yang meliputi bak sampah di setiap rumah tangga, bak sampah tempat limbah rumah tangga, bank sampah purwokeling, kerajinan sampah, pembuatan ecobrick, pembuatan takakura (sampah daun), pupuk cair (dari sampah organik), destilasi minyak BBM, Penggunaan energi baru terbarukan, konservasi dan penghematan energi, yang meliputi lampu penerangan tenaga surya; genting kaca, glas block, jendela kaca untuk ventilasi; pemanfaatan 
kompor baham sekam/sampah pengganti kompor LPG, Budidaya pertanian rendah emisi GRK, Peningkatan tutupan vegetasi, Pencegahan dan penanggulangan kebakaran hutan dan lahan dengan cara pembuatan peta rawan bencana dan longsor, pelatihan pemadaman kebakaran, pemasangan informasi larangan bakar sampah, pembuatan jalur evakuasi dan titik kumpul untuk tanggap darurat bencana kebakaran dan gempa bumi, tanda informasi jalur evakuasi dan titik kumpul, penyediaan APAR, alat tradisional untuk informasi bencana. (3) Aspek Keberlanjutan meliputi Kelompok masyarakat, Dukungan kebijakan, Dinamika kemasyarakatan, Kapasitas masyarakat, Keterlibatan pihak eksternal, Pengembangan kegiatan, dan Manfaat sosial, ekonomi, lingkungan dan pengurangan risiko bencana iklim

Dari rangkaian Proklim Purwokeling BPI yang dilakukan telah mendapat apresiasi dengan menjadi juara II Verifikasi Kampung Iklim Kota Semarang pada tahun 2017 dan di tahun 2019 mengikuti verifikasi kampung iklim tingkat nasional ("Purwokeling BPI Ikut Verifikasi Proklim Nasional," 2019). Apa yang sudah dilakukan Proklim Purwokeling BPI menjadi bagian dari komunikasi lingkungankarena menjadi proses komunikasi secara terencana dan strategis yang digunakan produk media untuk mendukung pembuatan kebijakan yang efektif, partisipasi masyarakat dan pelaksanaan proyek yang diarahkan pada kelestarian lingkungan [3].

Selama ini, komunikasi lingkungan dari kegiatan terdokumentasikan dengan publikasi media cetak, namun belum memaksimalkan publikasi digital yang jangkauannya mendunia karena bisa diakses dimana saja dan kapan saja. Setiap program kedaerahan tentunya menginginkan kegiatannya terpublikasikan dengan baik. Oleh karena itu dibutuhkan komunikasi yang terintergrasi dengan media digital agar jangkauan audiens lebih luas. Jika brand tidak masuk ke dunia digital kemungkinan besar akan tertinggal. Hal ini didasarkan pada perkembangan pesat teknologi dan internet, kita tidak terlepas dari kehidupan berbasis online [4]. Oleh karena itu, dibutuhkan keterlibatan dan kerjasama dengan perguruan tinggi untuk dapat memberikan pelatihan ketrampilan penulisan berbasis SEO sebagai penerapan keilmuan Public Relations dan Konten Kreatif. Proklim Purwokeling perlu pelatihan digital tentang apa yang sudah dilakukan, karena konten sudah ada namun belum disiarkan secara digital agar jangkauan lebih luas. Oleh karena itu, tim mengusulkan untuk melakukan pengabdian masyarakat dengan judul Pemanfaatan SEO sebagai Komunikasi Online Program Kampung Iklim Purwokeling Bhakti Persada Indah Semarang.

\section{METODE}

Komunikasi lingkungan diartikan sebagai cara untuk menyampaikan pesan kepada khalayak untuk menjaga keasrian lingkungan dengan berbagai saluran komunikasi. Bertujuan untuk membangun kesadaran diri khalayak untuk berkontribusi menjaga alam dan keberlanjutan ekosistem lingkungan [5]. Agar pesan dapat tersampaikan dengan baik maka perlu mengomunikasikan pesan hingga khalayak pun berusaha berperan dan ikut terlibat dalam pelestariannya. Untuk memaksimalkan komunikasi lingkungan maka ada beberapa lima langkah yang jadi elemen dan tahapan untuk dilakukan. Pertama, proses komunikasi yang terjadi harus efektif. Kedua, ada media yang digunakan dan dipahami dengan baik oleh khalayak. Ketiga, adanya kebijakan atau program lingkungan hidup yang mendukung sehingga penyampaian pesan dapat dilakukan. Keempat, keterlibatan untuk melaksanakan program lingkungan hidup yang telah dibuat. Kelima, memahami fungsi lingkungan hidup dan program yang dijalankan oleh masyarakat dan mencari solusi untuk menjaga lingkungan hidup 
Komunikasi lingkungan ini bisa dipublikasikan menggunakan media digital dengan mengoptimalisasi SEO. SEO adalah teknik yang memungkinkan situs web muncul di daftar hasil teratas dari mesin pencari dengan menggunakan kata kunci tertentu [6]. Penulisan release ke media online berbasis SEO dapat menimbulkan keterbacaan yang tinggi. Komunikasi yang disampaikan pun dapat lebih kaya dengan memanfaatkan saluran media digital dibandingkan dengan media cetak yang konvensional. Pemanfaatan media digital untuk menyampaikan informasi juga membuat jangkauan khalayak lebih luas bahkan hingga global. SEO secara langsung berkorelasi dengan rasio klik laman dan frekuensi kunjungan, sehingga memudahkan dalam visibiltas konten [7]. Setelah memahami pentingnya SEO sebagai teknik komunikasi lingkungan maka saluran media menjadi perangkat yang penting. Salah satunya dengan pemanfaatan media digital yang digunakan sebagai sosialisasi untuk pelatihan kesadaran lingkungan. Konten yang persuasif sehingga membuat audiens mudah terbujuk dan melakukan sadar lingkungan [8].

Pelatihan untuk memanfaatkan SEO sebagai komunikasi online Program Kampung Iklim Purwokeling Bhakti Persada Indah Semarang dengan membuat konten yang menarik dan tepat bisa semakin menarik masyarakat untuk lebih peduli dengan lingkungan dan menginspirasi melakukan hal yang sama demi keberlanjutan ekosistem.

1. Penilaian

a. Analisis Situasi dan Identifikasi Masalah

Tim Pengusul Pengabdian Masyarakat mengidentifikasi kegiatan-kegiatan yang dilakukan mitra yaitu Proklim Purwokeling BPI

b. Analisis Pihak/Pelaku yang terlibat

Tim Pengusul mengidentifikasi persepsi mengenai identitas wilayah sebagai actual identity brand [9]. Hal ini meliputi bagaimana komunikasi yang sudah dilakukan, fisik lingkungan, word of mouth mengenai Proklim Purwokeling BPI. Tim pengusul melakukan pre test saat mengidentifikasi persepsi.

c. Komunikasi Objektif

Menentukan tujuan program pelaksanaan

2. Perencanaan

a. Pengembangan Strategi Komunikasi

Merencanakan pelatihan penulisan digital dengan penulisan kreatif berbasis SEO. Selain itu penyusunan proposal untuk mitra Proklim Purwokeling BPI.

b. Memotivasi dan Memobilisir Masyarakat

Melakukan rapat antara Tim Pengusul dan mitra Proklim Purwokeling BPI untuk dapat terlibat dalam pelatihan pemanfaatan SEO sebagai komunikasi online.

c. Pemilihan Media

Menyusun pemanfaatan media online dan Youtube

3. Produksi

a. Desain Pesan yang disampaikan

Setelah menentukan value dari beragam kegiatan Proklim Purwokeling BPI, mulai mengangkat konten yang akan dipublikasikan di media.digital

b. Produksi media

Pelatihan Kreatif Konten Digital yang meliputi memberikan surprise effect, konektivitas dengan audiens, fantasy, mengangkat trending topic dalam isu lingkungan. 
4. Aksi dan refleksi

a. Penyebaran melalui media dan implementasinya

Implementasi dari hasil pelatihan ketrampilan kreatif konten digital di diunggah di akun resmi instagram dan Youtube. Selain itu juga disebarluaskan di media lokal Jawa Tengah sebagai pendukung karena media lokal juga memiliki media online.

b. Proses dokumentasi, monitoring dan evaluasi

Tim pengusul dan mitra melakukan dokumentasi digital, monitoring media

\section{HASIL DAN PEMBAHASAN}

\section{A. Pelaksanaan Kegiatan}

Bentuk dari upaya untuk lebih memasyarakatkan kegiatan peduli lingkungan yang telah dirintis oleh kampung iklim puwokeling Semarang agar diketahui oleh lebih banyak stakeholders atau masyarakat melalui media digital dilakukan antara tim pengabdian Udinus dengan pengurus dan anggota kampung iklam Purwokeling melalui serangkaian tahapan. Setelah melakukan observasi dengan melakukan analisa SWOT (Strengths (Kekuatan), Weaknesses (Kelemahan), Opportunities (Peluang), dan Threats (Ancaman), atas apa yang dimiliki pada kampung yang telah mampu menggerakkan warga dilingkungan mereka sendiri untuk peduli dengan lingkungan sendiri dengan kesadasaran pengelolaan sampah baik organic maupun unorganik, mengoptimalkan sumur resapan, pembuatan tanggul, penghijauan. Maka sosialisasi ke masyarakat yang lebih luas ini menjadi penting untuk menularkan virus kebaikan ini.

Udinus selaku sebagai kampus yang memiliki kompetensi terkait komunikasi dengan adanya prodi ilmu komunikasi yang di dalamnya terdapat muatan terkait pengembangan komunikasi dengan media, lingkungan dan penulisan kreatif dalam konten digital melakukan pelatihan terkait penulisan kegiatan dalam konteks pemberitaan dan publikasi dengan beragam media. Data atau informasi tentang subjek yang tidak diketahui biasanya dicari di halaman pertama mesin pencari. Karena itu, penting untuk memindahkan halaman web ke daftar teratas mesin pencari untuk memperkenalkannya dengan lebih baik. Untuk mencapai ini, optimisasi mesin pencari harus digunakan oleh pengembang situs web. Karena, dimungkinkan untuk memindahkan halaman web ke halaman pertama mesin pencari dengan hanya menggunakan beberapa aturan pengoptimalan yang diperlukan. SEO memungkinkan situs web muncul di daftar hasil teratas mesin pencari untuk beberapa kata kunci tertentu [6]. Maka, konten berbasis SEO ini dilakukan dengan analisis kata kunci untuk pengoptimalan. Dengan menargetkan audiens SEO maka harus melakukan penelitian apa yang akan ditempatkan audiens sebagai kata kunci di dalam mesin pencari. Analisis kata kunci ini disediakan oleh beberapa alat analisis kata kunci seperti Google Adwords [10].

Kegiatan yang bertujuan untuk mengoptimalkan pemanfaatan media digital yang digunakan sebagai sosialisasi untuk pelatihan kesadaran lingkungan dengan konten persuasif ini dimulai dengan memberikan bekal kepada anggota dan pengurus kampung proklim purwokeling. Materi terkait paparan edukasi tentang perkembangan media digital dan memproduksi konten pada media dapat dilakukan oleh siapa saja. Materi ini dismpaikan oleh anggota pengabdian Switta Amalia Hapsari yang juga tim pengajar konten digital dan penulisan kreatif. Edukasi terkait media digital dilanjutkan dengan materi terkait SEO atau Search Engine optimization dan kesadaran dalam 
berkomunikasi lingkungan oleh ketua pengabdian Udinus Heni Indrayani . Serta materi Komunikasi persuasif dan penulisan jurnalistik oleh anggota Mukaromah.

Setelah melakukan kegiatan sosialisasi terkait edukasi perkembangan media dilanjutkan dengan Pelatihan penulisan konten digital berbasis SEO kepada peserta dan pengurus kampung proklim pruwokeling dan didampingi oleh dosen dan mahasiswa Udinus yang terlibat. Rangkaian kegiatan ini dilanjutkan dengan praktek penulisan hingga proses pengiriman artikel terkait News Release menggunakan SEO.

Hasilnya adalah dimuatnya beberapa pemberitaan terkait kampung iklim purwokeling Semarang pada periode pengabdian masyarakat dilakukan, publikasi terkait kegiatan kampung iklim ke berbagai media, kegiatan pelatihan pembuatan ecobrict secara online dengan peserta yang berasal dari luar warga atau pengurus purwokeling dengan menggunakan media zoom meeting dan yang tidak ketinggalan kampung iklim Purwokeling memiliki akum media instagram yang dapat mengunggah konten dan kegiatannya secara mandiri oleh pengurus kampung iklim proklim ke khalayak.

Berikut ini adalah hasil kinerja dari kegiatan pengabdian yang dilakukan mulai dari program berkelanjutan sejak November 2019 hingga awal Februari 2021 tersebut yang sudah terpublikasi di portal https://jateng.antaranews.com/, https://www.brilio.net/, Suaramerdeka.com ,mediaini.com dan media instagram @proklimpurwokeling

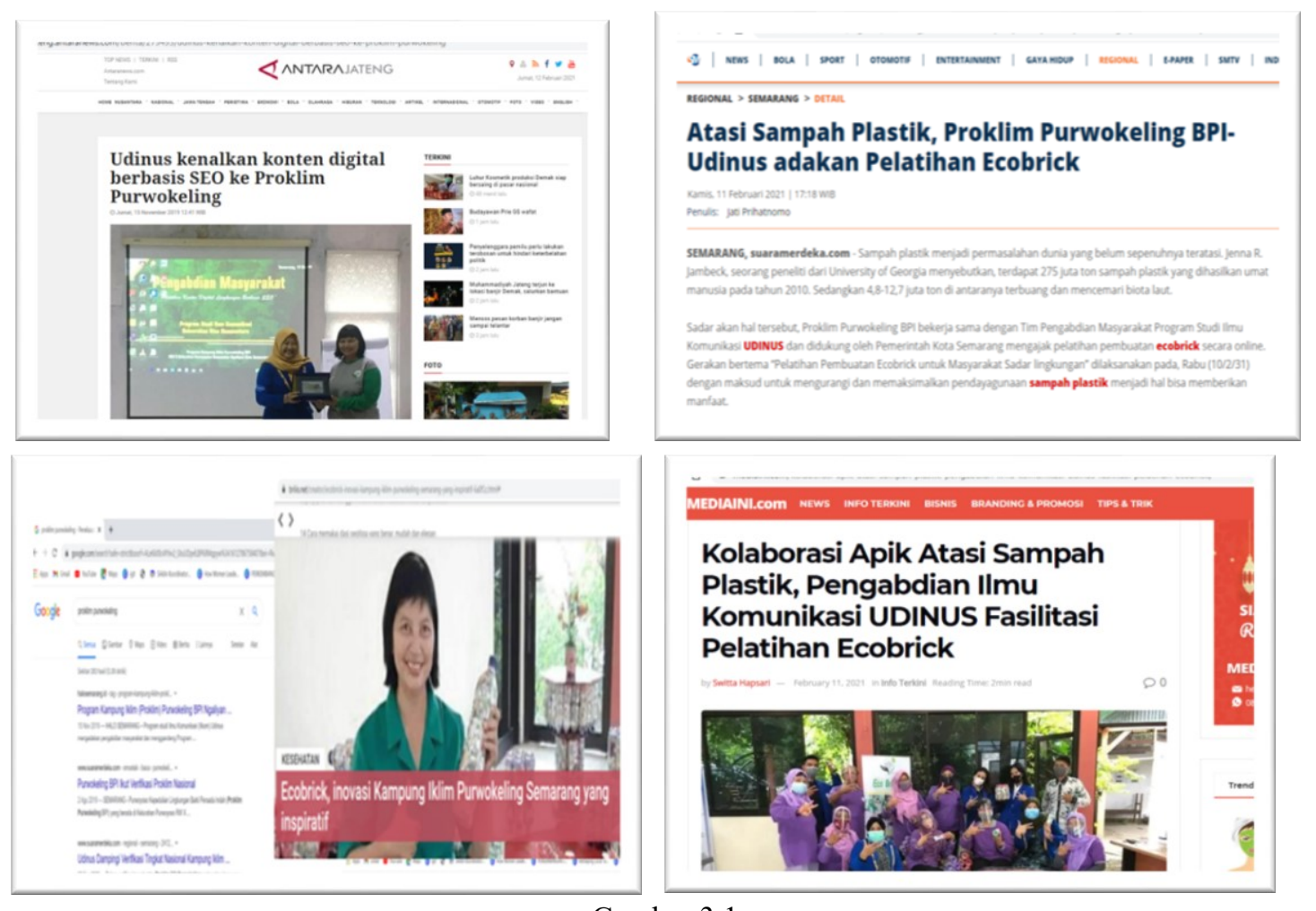

Gambar 3.1

Hasil pelaksanaan pengabdian dan publikasi di beragam media Sumber: rangkuman berbagai sumber oleh tim

\section{B. Peran Tim Pengabdiaan dan Peserta}

Pera peserta dalam rangkaian kegiatan pengabdian masyarakat terkait penulisan konten, membuat tulisan berbasis SEO, menulis News Relesase hingga sosialisasi kegiatan 
menggunakan media online seperti Zoom berjalan dengan antusias dan sesuai dengan tujuan yang diharapkan.

Guna lebih memudahkan pemahaman terkait peran serta Peserta berikut ini adalah tabel tahapan dan peran serta dari Tim Pengabdian Udinus dan Peserta sebagaimana terlihat dari tabel 3.1

Tabel 3.1 Peran SertaPeserta Kegiatan

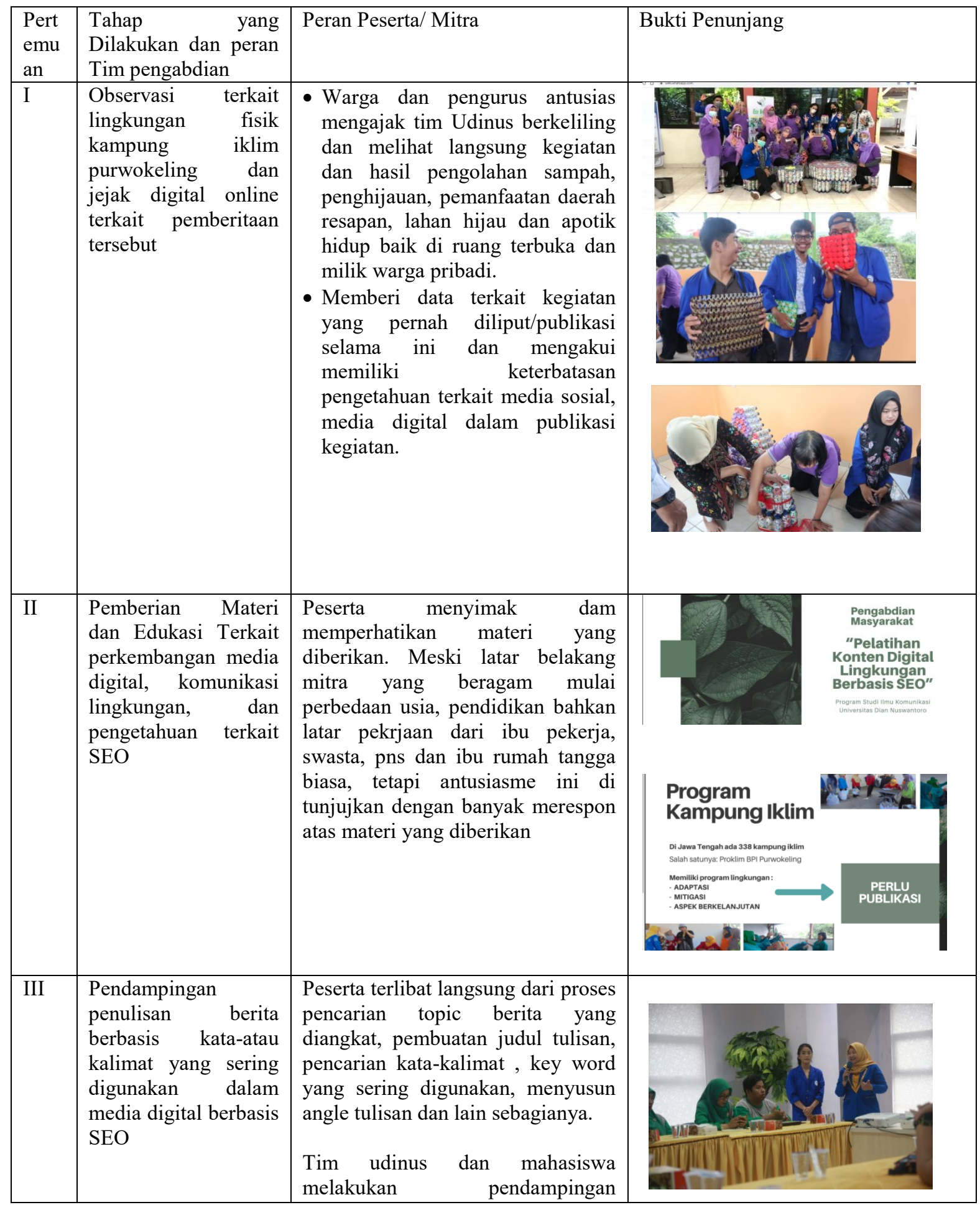


Abdimasku, Vol. 4, No. 3, September 2021: 205-215

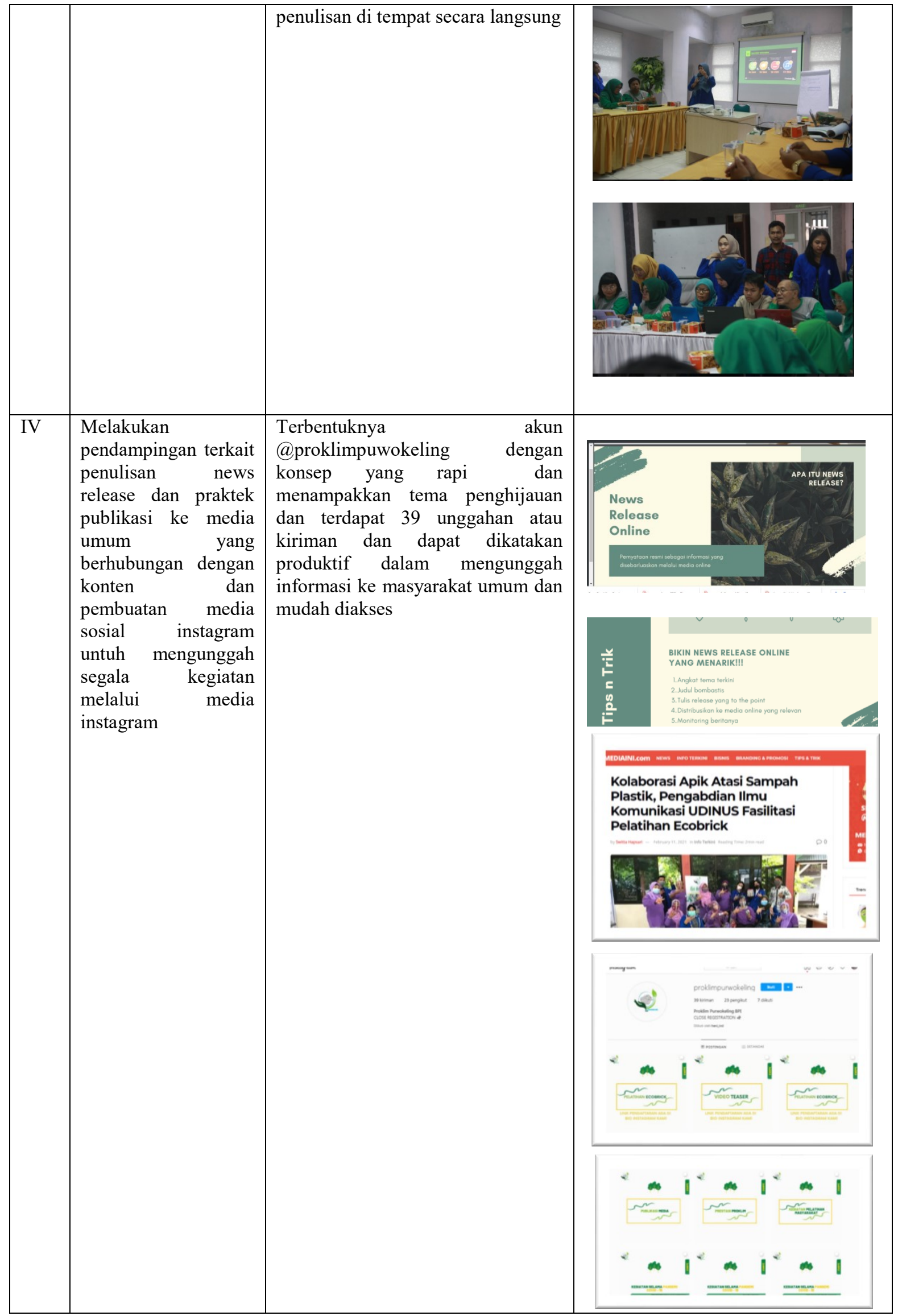




\begin{tabular}{|c|c|c|c|}
\hline & & & $\begin{array}{l}\text { Tampilan akun instagram } \\
\text { @proklimpurwokeling yang sudah } \\
\text { dikelola }\end{array}$ \\
\hline $\mathrm{V}$ & $\begin{array}{l}\text { Melakukan sosialisasi } \\
\text { terkait kegiatan } \\
\text { kampung proklim } \\
\text { purwokeling dengan } \\
\text { menggunakan media } \\
\text { daring ZOOM di } \\
\text { tengah pandemic } \\
\text { sehingga kegiatan } \\
\text { kampung ini masih } \\
\text { bisa dilakukan meski } \\
\text { terkendala jarak dan } \\
\text { keadaan. }\end{array}$ & $\begin{array}{l}\text { Melakukan bersama dengan tim } \\
\text { Udinus dan mahasiswa dibalai RW } \\
\text { Purwokeling kegiatan daring } \\
\text { online dengan media zoom terkait } \\
\text { Pelatihan Pembuatan Ecobrick } \\
\text { untuk Masyarakat } \\
\text { Lingkungan } \\
\text { Pada tanggal 10 Februari } 2021 \\
\text { Dengan } \\
\text { https://zoom.us/j/99278164007?pw } \\
\text { d=ZGtqY0lraFFnT08zM3IyM3hLd } \\
\text { jZqZz09. } \\
\text { Kegiatan ini mendapatkan respon } \\
\text { dari peserta diluar daerah dengan } \\
\text { antusias. tercatat peserta ada yang } \\
\text { dari Aceh, Banjarmasin, Makasar, } \\
\text { Purworejo, Gorontalo dll } \\
\text { Ketua Proklim Purwokeling Eko } \\
\text { Gustini sebagai pemateri pelatihan } \\
\text { dan Tim Humas Pemkot Semarang } \\
\text { Siswo Purnomo dan Heni indrayani } \\
\text { selaku ketua tim dari Udinus }\end{array}$ & 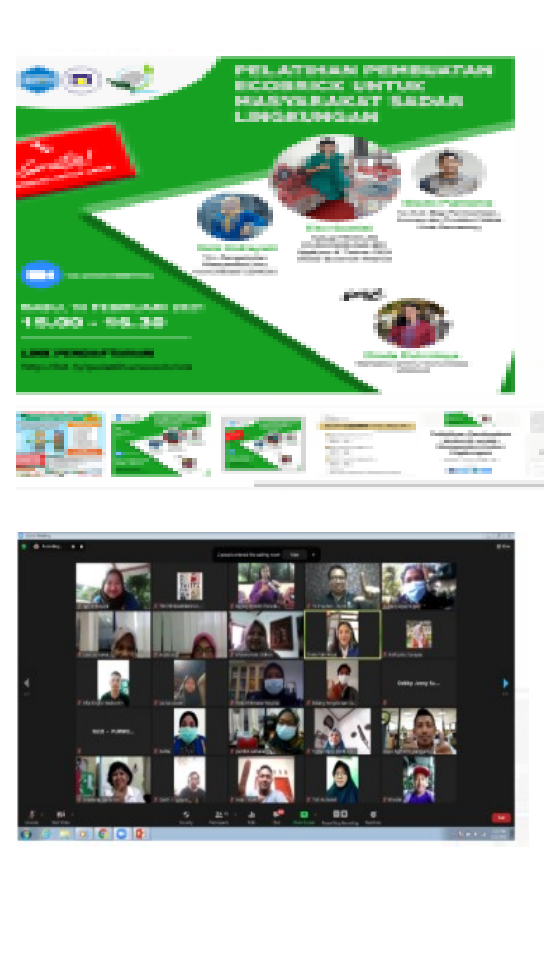 \\
\hline
\end{tabular}

Dalam bidang ilmu komunikasi mempublikasikan kegiatan adalah hal yang penting dilakukan terkait stakeholders atau pihak pihak yang terkait dan agar tujuan yang ingin didapatkan lebih mudah tersampaikan. Salah satu jalan untuk memudahkan tercapainya publikasi ini adalah melalui media massa. Hal ini sebagaimana konsep dalam komunikasi massa bahwa salah satu tugas media massa adalah menjalankan fungsi untuk menyampaikan informasi, pendidikan selain fungsi-fungsi lainnya seperti hiburan, menyatukan dan kontrol sosial [11]. Kampung atau partisipasi warga yang peduli terhadap lingkungan terlebih dalam keadaan iklim dan cuaca yang tidak menentu dan rawan bencana perlu sekali digalakkan dan bukan hanya tugas dari pemerintah semata.

Dengan adanya kemampuan menulis berita, news release oleh warga masyarakat di kampung ini harapannya warga selalin dapat berpartisipasi pada perawatan lingkungan di sekelilingnya juga dapat menyebarkan informasi dan pengetahuan ini kepada khalayak yang lebuh luas dengan tetap berpegang pada konten penulisan yang bertanggung jawab, berpijak pada data dan tidak terjebak pada berita yang kurang bertanggung jawab atau Hoax, sehingga sebenarnya kegiatan pengabdian ini selain penambahan skill praktis dalam penulisan media juga merupakan bagian kegiatan literasi informasi dan media sebagai bagian tanggung jawab sosial kemasyarakatan perguruan tinggi.

\section{KESIMPULAN DAN SARAN}

Kegiatan pengabdian masyarakat adalah wujud langsung partisipasi masyarakat akademik dalam hal ini perguruan tinggi dengan masyarakat. Kemampuan penulisan berita, news realease, penulisan konten yang bertanggung jawab menjadi hal yang 
penting dilakukan di tengah kenyataan banyaknya keterbatasan dalam penulisan informasi yang bertanggung jawab sehingga memunculkan banyak berita hoax yang terjadi. LIterasi media adalah bagian dari informasi yang harus disampaikan kepada masyarakat.

Penulisan konten media dengan tema lingkungan menjadi isu yang menarik disaat kesadaran masyarakat untuk peduli lingkungan perlu ditIngkatkan dan terjadinya banyak bencana karena perusakan lingkungan. Kampung Proklim Purwokeling Semarang adalah salahsatu wujud partisipasi warga yang peduli terhadap lingkungannya dan gerakan ini perlu disosialisasikan secara luas dengan menyampaikan kegiatan dan informasi ke mdia massa sebagai virus yang positif untuk dapat terus dikembangkan sehingga menjadi gerakan massif di masyarakat yang belum tersadar akan pentingnya kepedulain lingkungan.

\section{UCAPAN TERIMA KASIH}

Kami berterima kasih kepada seluruh warga Program Kampung Iklim Purwokeling Bhakti Persada Indah Semarang, atas kesempatan yang telah diberikan dalam membagikan ilmu pengetahuan dan pelatihan yang diberikan untuk dapat meningkatkan kualitas sumber daya manusia. Kami juga ingin berterima kasih kepada Universitas Dian Nuswantoro selaku kampus yang meberikan kesempatan pada Dosen dan mahasiswa terlibat aktif dalam kegiatan kemasyarakat sebagai bagian dari tri darma perguruan tinggi serta pihakpihak yang telah membantu kami dalam memberikan masukan dan informasi yang bermanfaat dalam menyelesaikan penelitian dan pengabdian masyarakat ini.

\section{DAFTAR PUSTAKA}

[1] D. Asteria, H. Herdiansyah, and I. W. A. Apriana, "Women's Environmental Literacy As Social Capital in Environmental Management for Environmental Security of Urban Area," IOP Conf. Ser. Earth Environ. Sci., vol. 30, no. 1, 2016.

[2] A. N. Rizqi, "Jateng Miliki 338 Kampung Iklim, Terbanyak di Indonesia," semarang.bisnis.com, 2019. [Online]. Available: https://semarang.bisnis.com/read/20190724/535/1128359/jateng-miliki-338kampung-iklim-terbanyak-di-indonesia.

[3] P. Lestari, S. B. Kusumayudha, E. T. Paripurno, and B. Ramadhaniyanto, "Komunikasi Lingkungan untuk Mitigasi Bencana Erupsi Gunung Sinabung," $J$. ASPIKOM, vol. 3, no. 1, pp. 56-64, 2016.

[4] F. Yusuf, "Optimalisasi Program Branding Dan Aktivasi Merek Di Era Digital," J. Komun., vol. 7, no. 1, pp. 7-13, 2016.

[5] S. Azeharie and S. Paramita, "Pemberdayaan Masyarakat Melalui Komunikasi Lingkungan Di Desa Karang Patih,Kabupaten Ponorogo," in Pemberdayaan Masyarakat Melalui Komunikasi Lingkungan Di Desa Karang Patih,Kabupaten Ponorogo., 2015, pp. 11-23.

[6] N. Yalçin and U. Köse, "What is search engine optimization: SEO?," Procedia Soc. Behav. Sci., vol. 9, no. July 2009, pp. 487-493, 2010.

[7] G. Egri and C. Bayrak, "The Role of Search Engine Optimization on Keeping the User on the Site," Procedia Comput. Sci., vol. 36, no. C, pp. 335-342, 2014. 
[8] A. Harmoni, "Media Richness Theory dan Potensi Website sebagai Media Komunikasi CSR oleh Perusahaan," Gunadarma Univ. Repos., no. 100, 2014.

[9] M. R. Yananda and U. Salamah, Branding Tempat: Membangun Kota, Kabupaten, dan Provinsi Berbasis Identitas. Jakarta: MaknaInformasi, 2014.

[10] K. Choudhari and V. K. Bhalla, "Video Search Engine Optimization Using Keyword and Feature Analysis," Procedia Comput. Sci., vol. 58, pp. 691-697, 2015.

[11] D. McQuail, Teori Komunikasi Massa. Jakarta: Erlangga, 1994. 